\title{
PERAN ONLINE ADVERTISING PADA PEMASARAN AXIS
}

\author{
Devita Eka Santi \\ Universitas Indonesia
}

\begin{abstract}
In this era of the growth of technology, the internet user is significantly increasing each year. During advertising activities, companies start using internet to advertise their products or services. Online advertising activities keep increasing dramatically. Advertising business do much more activities on internet to send message as marketing form to audiences. There are various online advertising using the internet nowadays. Online advertising is done to build awareness until purchase decision of the products or services which has been advertised to the audiences. In this research has been described various types of online advertising that has been done by Axis, such as search engine optimization, search engine marketing, social media advertising, and placement banner. Online advertising which has been done by Axis is to build awareness, consideration, purchase decision to the audiences who access the online advertising. Online advertising is done to reach the target audiences of Axis and instill Axis brand in the mind of the audiences (top of mind)
\end{abstract}

\author{
Keywords \\ Advertising, Online Advertising, \\ Build Awareness, Purchase \\ Decision
}

Correspondence Contact devitaes@gmail.com

\section{PENDAHULUAN}

Perkembangan teknologi saat ini menjadikan internet sebagai salah satu sumber konsumsi informasi yang cukup besar. Munculnya internet telah secara dramatasi mengubah pola preferensi mencari sumber informasi. Sumber-sumber informasi yang secara tradisional popular seperti orang-orang, surat kabar, majalah, dan televisi, secara bertahap telah digantikan oleh sumber-sumber internet (Oh, Oh, \& Shah, 2008). Salah satu kegunaan yang didapatkan melalui internet yaitu internet dapat menjadi media periklanan tanpa menghabiskan banyak biaya. Internet juga dapat menjadi media iklan yang kemampuannya dapat menjangkau khalayak luas tanpa batasan waktu dan aksesibilitas (Anusha, 2016).

Perkembangan dan jumlah pengguna internet yang terus bertambah dari tahun ke tahun menjadikan internet menjadi salah satu alat untuk komunikasi, hiburan, edukasi, dan penjualan elektronik. Di dalam dunia bisnis, internet sudah mengubah cara berbisnis yang mulanya tradisional menjadi digital. Menurut Silk et al (2001) internet sudah muncul sebagai media periklanan. Banyak perusahaan sudah menggunakan internet untuk mengiklankan produk dan jasa mereka. Internet juga dianggap sebagai saluran pemasaran langsung yang paling signifikan untuk pasar global sehingga perusahaan mengeluarkan biaya cukup besar untuk membangun iklan di internet sebagai bentuk investasi mereka (Lim, Yap, \& Lau, 2011).

Internet yang terus tumbuh menjadikan para pengiklan semakin tertarik untuk menjadikan dunia digital sebagai sumber yang lebih produktif untuk konsumen dalam mengkonsumsi iklan. Perusahaan saat ini pada umumnya termotivasi untuk memberikan alokasi lebih kepada biaya pemasaran online seiring dengan meningkatnya konsumen yang menggunakan media online dalam mencari informasi. Di dalam periklanan online, khalayak dapat memilih apakah mereka akan melihat iklan maupun mengabaikan iklan tersebut. 
Di dalam konteks display ads, terdapat studi mengenai dampak dari terpaan iklan online melalui tingkah laku, kesadaran merek jangka panjang, dan keputusan pembelian kembali. Penelitian juga menggali potensi iklan display yang ditargetlan serta konsekuensi dari gangguannya. Lewis dan Reiley (2011) menggunakan eksperimen acak untuk mengukur efek kausal dari iklan tampilan online pada penjualan ritel offline. Dalam konteks pencarian berbayar, para peneliti telah focus pada pemahaman strategi periklanan yang optimal dalam lingkungan mesin pencari yang kompleks. Ghose dan Yang (2009) mengadopsi pendekatan spesifik kata kunci untuk memahami kinerja masing-masing kata kunci dan memandu keputusan investasi kata kunci yang optimal. Wiesel et al (2011) memodelkan perkembangan konsumen melalui corong pembelian dan menjelaskan bagaimana iklan online dapat mendorong penjualan di saluran offline (Kireyev, Pauwels, \& Gupta, 2016).

Dengan kemajuan yang cukup pesat di dalam industri komputer, banyak perusahaan menjadikan internet sebagai bagian dari bauran media periklanan mereka untuk mengambil keuntungan dari teknologi online. Ducofffe (1996) menyebutkan bahwa internet telah menjadi platform periklanan yang popular karena pemasar menemukan bahwa internet memiliki kontrol dan fleksibilitas yang lebih besar atas materi iklan. Internet digunakan sebagai alat komunikasi pemasaran yang efisien, maka baik praktisi maupun cendekiawan tertarik untuk memahami bagaimana mengambil keuntungan penuh dan memaksimalkan nilai media komunikasi ini. Dengan meningkatnya popularitas periklanan online, area kritis dalam penelitian internet akan menentukan efektivitas periklanan online. Penelitian yang lebih sistematis diperlukan untuk menentukan nilai sebenarnya dari perdagangan di internet, khususnya perannya sebagai media atau alat periklanan (Lim et al., 2011). Di dalam beberapa penelitian sebelumnya mengenai efektivitas online advertising, salah satunya yaitu Ahmed et al yang menyebutkan bahwa peran saluran media digitial online untuk menetapkan efektivitas iklan media digital dapat membangun brand sustainability. Penelitiannya meliputi sektor jasa dan sektor manufaktur PT Industri Pakistan dimana online advertising berhasil menggunakan semua saluran media digital untuk mengiklankan merek mereka. Hasil dari penelitian yang dilakukan menyimpulkan bahwa saluran media digital online memiliki pengaruh positif dan signifikan terhadap efektivitas online dalam brand sustainability (Ahmed et al., 2019).

Periklanan melalui digital juga melalui proses pengiriman pesan dimana pengiklan membentuk suatu iklan melalui internet sebagai mediumnya kepada konsumen sehingga iklan tersebut dapat memberikan efek kepada konsumen baik itu efek kedasaran akan merek hingga efek pembelian. Saat ini, hampir semua perusahaan menggunakan aktivitas periklanan online untuk memperkenalkan produknya hingga mencapai target penjualan. Salah satu perusahaan yang menjalankan tools advertising online yaitu Axis.

Kementerian Komunikasi dan Informatika (Kominfo) mengumumkan hasil registrasi jumlah nomor pelanggan prabayar yang sudah registrasi ulang maupun registrasi baru per tanggal 30 April 2018 dengan hasil sebanyak 254,792,159 pelanggan sehingga dapat dilihat bahwa per tahun 2018 lalu, terdapat sekitar 254 juta pengguna telekomunikasi yang di dalamnya terdapat persaingan operator seluler (Hutabarat, 2018).

Axis merupakan salah satu produk telekomunikasi dari XL Axiata dimana Axis kembali diluncurkan pada 30 Maret 2015 dengan menyediakan fasilitas telepon, data internet, dan SMS untuk seluruh masyarakat di Indonesia. Persaingan yang ketat dalam dunia penyedia layanan operator seluler di Indonesia membuat Axis menjalankan strategi marketing dan periklanan yang kreatif untuk mencapai target khalayak mereka. Dengan memanfaatkan internet untuk menjangkau khalayak yang lebih luas, selain melakukan pemasaran secara offline, Axis juga menggunakan online advertising mengingat saat ini jumlah pengguna internet dari tahun ke tahun terus meningkat (“Tentang Axis," 2017). 
Proses penyampaian pesan yang dikemas oleh Axis melalui online advertising merupakan salah satu strategi pemasaran yang dijalankan sehingga dapat memunculkan kesadaran oleh khalayak akan hadirnya Axis sebagai salah satu penyedia layanan operator seluler dengan harga terjangkau sehingga tujuan utama yang ingin dicapai adalah adanya penggunaan kartu Axis. Proses penyampaian pesan yang berulang melalui adanya iklan di internet diharapkan dapat memberikan kesadaran merek kepada khalayak sebagai langkah awal di dalam strategi pemasaran yang dijalankan oleh Axis dimana nantinya Axis menjadi produk telekomunikasi yang diingat oleh masyarakat luas dan dapat dipercayai sebagai produk telekomunikasi yang digunakan sehari-hari.

\section{METODOLOGI}

Metode penelitian yang digunakan yaitu menggunakan metode penelitian kualitatif deskriptif. Metode deskriptif merupakan metode di dalam meneliti status sekelompok manusia, suatu set kondisi, suatu obyek, atau suatu kelas peristiwa pada masa saat ini. Metode deskriptif adalah metode untuk pencarian fakta melalui interpretasi yang tepat (Whitney, 1960). Data yang dikumpulkan di dalam penelitian ini yaitu melalui wawancara mendalam, observasi, dan studi literatur. Data primer diperoleh melalui proses wawancara mendalam kepada dua orang informan melalui teknik sampel purposive yaitu Digital Campaign Youth Marketing Communication Axis dan Marketing Communication Axis di mana ke dua informan tersebut merupakan bagian dari tim marketing communication Axis yang menjalankan strategi online advertising dan marketing communication. Sementara untuk data sekunder, penulis mendapatkan melalui buku, jurnal, studi literatur penelitian sebelumnya, dan media sosial Axis yang memiliki kaitan dengan penelitian yang saat ini dilaksanakan.

Penulis menggunakan paradigma konstruktivis karena di dalam penelitian ini bertujuan untuk menjabarkan strategi online advertising yang dilakukan oleh Axis dalam kegiatan pemasaran produk mereka.

Di dalam penelitian ini digambarkan bagaimana jenis-jenis online advertising yang dijalankan oleh Axis sebagai salah satu pelaku telekomunikasi di Indonesia di dalam memperkenalkan produknya serta menarik konsumen agar menggunakan produk tersebut. Dengan adanya perkembangan internet serta tingkat kenaikan pengguna internet yang terus bertambah dari tahun ke tahun, maka Axis memanfaatkan internet dalam melakukan aktivitas periklanannya.

\section{HASIL DAN PEMBAHASAN}

\section{Strategi Pemasaran Axis}

Menurut Kotler, marketing merupakan sebuah proses dimana perusahaan membentuk nilai untuk konsumen, berkomunikasi dan mengirimkan pesan kepada konsumen, serta membangun hubungan kuat untuk mengambil nilai-nilai dari konsumen sebagai imbalannya. Selain dilakukan oleh perusahaan, kegiatan marketing juga dapat dilakukan oleh organisasi non-profit. Saat ini kegiatan marketing tidak hanya diartikan sebagai bentuk penjualan memberitahukan dan menjual - tetapi juga untuk memuaskan kebutuhan konsumen. Jika pemasar dapat memahami kebutuhan dari konsumen, mengembangkan produk yang menyediakan nilai pelanggan dan harga yang unggul, serta mendistribusikan dan mempromosikan produk atau jasa tersebut dengan efektif, maka produk atau jasa tersebut akan terjual dengan mudah (Kotler, Burton, Deans, Linen, \& Armstrong, 2013).

Marketing dapat didefinisikan sebagai sebuah aktivitas, mengatur institusi, dan proses untuk menciptakan, berkomunikasi, mengirimkan, dan menukar penawaran yang bernilai bagi pelanggan, klien, rekanan, dan masyarakat yang lebih luas (Armstrong, Stewart, Denize, \& 
Kotler, 2015). Strategi pemasaran sebuah perusahaan menguraikan pelanggan mana yang akan dilayani perusahaan dan bagaimana hal itu akan menciptakan nilai bagi pelanggan tersebut. Selanjutnya program pemasaran akan membangun hubungan dengan pelanggan melalui mengubah strategi pemasaran menjadi sebuah tindakan (Armstrong et al., 2015).

Ketika teknologi semakin tumbuh, dunia marketing ikut bergerak ke era digital. Perkembangan teknologi saat ini membentuk eral digital sehingga terdapat perkembangan yang cukup besar dalam komunikasi online, informasi, dan teknologi-teknologi digital lainnya yang memiliki dampak cukup besar dalam cara suatu perusahaan membawa nilai kepada konsumen mereka. Era digital saat ini memungkinkan para pemasar dengan cara baru yang sudah ada untuk mempelajari mengenai konsumen, membuat produk dan layanan yang disesuaikan dengan kebutuhan pelanggan. Hal ini juga membantu para pemasar untuk berkomunikasi dengan konsumen ke dalam kelompok yang lebih luas atau pun komunikasi satu-satu. Teknologi digital juga membawa gelombang baru pada komunikasi, periklanan, dan alat membangun hubungan yang terdiri dari online advertising, alat berbagi video, dan telepon seluler hingga aplikasi web, serta jaringan sosial online (Kotler et al., 2013).

Kegiatan marketing saat ini sudah mulai memanfaatkan internet karena melihat besarnya pengguna internet yang terus meningkat dari tahun ke tahun. Internet marketing atau yang biasa disebut dengan web marketing atau e-marketing merupakan kegiatan pemasaran (secara umum promosi) dari suatu produk atau jasa melalui internet. Internet marketing dianggap memiliki cakupan luas karena tidak hanya mengacu pada pemasaran di internet, tetapi juga termasuk kegiatan marketing yang dilakukan melalui e-mail ataupun wireless media. Di dalam sistem manahemen hubungan pelanggan elektronik dan data pelanggan digital juga sering dikelompokkan bersama di bawah pemasaran internet (Priyanka, 2012).

Online marketing sedang merevolusi cara perusahaan bersaing di antara masing-masing. Pemasar di seluruh dunia telah menyadari pentingnya pemasaran online dan keuntungannya dibandingkan dengan marketing tradisional. Online marketing memiliki banyak keuntungan seperti dapat menjangkau konsumen lebih efektif, biaya yang efektif, hasilnya dapat diukur, dan dapat dipersonalisasikan. Namun terdapat kontrak dari online marketing yaitu tingkat kompetisi yang sangat tinggi (Schwarzl, 2015).

Axis melakukan kegiatan pemasaran untuk mencapai target penjualan kartunya sehingga dapat menjadi salah satu operator seluler dengan pengguna terbanyak di Indonesia. Di dalam mencapai tujuan untuk meningkatkan jumlah pelanggan Axis dari tahun ke tahun, Axis menjalankan berbagai kegiatan campaign untuk membangun brand awareness masyarakat terhadap produknya sehingga hasil akhir diharapkan dapat mempengaruhi keputusan pembelian khalayak untuk menggunakan Axis. Untuk menunjang kegiatan pemasaran yang dapat menarik perhatian khalayak, Axis menciptakan kampanye periklanan melalui digital melihat bahwa saat ini penggunaan teknologi digital semakin bertumbuh pesat.

Berdasarkan hasil wawancara dengan Digital Campaign Youth Marketing Communication Axis dan Marketing Communication Axis, Ibu Sharon, berikut penuturannya mengenai platform yang digunakan dalam online advertising Axis:

"Platformnya ada Youtube, ada Instagram, Facebook, ada Line, detik.com, ada in app game, basically kita berusaha buat placement di semua platform yang sesuai dengan target market Axis" 
Kegiatan pemasaran yang dilakukan oleh Axis yaitu untuk mengirimkan pesan kepada target khalayak dimana di dalam pesan itu berisi informasi mengenai produk yang ditawarkan oleh Axis dan bagaimana perbedaan produk tersebut dengan operator seluler lainnya sehingga akan muncul kesadaran akan informasi produk Axis oleh khalayak yang melihat iklan. Ketika kesadaran akan produk Axis muncul, maka langkah selanjutnya yang dilakukan yaitu bagaimana membuat khalayak memilih untuk menggunakan Axis.

Digital Campaign Youth Marketing Communication Axis dan Marketing Communication Axis juga menambahkan fungsi dari masing-masing platform yang digunakan oleh Axis:

"Untuk Twitter, Instagram kita masukan ke kategori sosial media atau social app, lalu YouTube itu video, terus in app game itu kita appear di game-game yang punya inventory ads kalo pernah denger rewarded video ketika kamu nonton iklan terus nanti dapetin poin atau koin untuk game itu"

\section{Jenis Online Advertising Axis}

Online advertising dimulai pada tahun 1994 ketika HotWired menjual pertama kalinya banner ads kepada beberapa pengiklan. Porsi dari periklanan yang dilakukan melalui online akan meningkat secara signifikan selama perkembangan perangkat seperti mobile seluler dan televisi dapat dihubungkan dengan internet dan saat ini masyarakat menghabiskan lebih banyak waktu pada perangkat yang memiliki jaringan internet tersebut. Industri online advertising meledak kehadapan public pada tahun 2007. Harga saham Google meroket tinggi dan langkahnya menuju industri seperti perangkat luna pengolah kata, pembayaran online, dan telepon seluler menarik perhatian yang cukup signifikan. Lebih dari 500 artikel di Google muncul di New York Times, Wall st. Journal, dan Financial Times sepanjang tahun. Lalu bisnis mulai memindahkan upaya periklanan mereka ke berbagai bidang dengan memanfaatkan media sosial pada tahun 2009. Media sosial mencakup alat jejaring sosial seperti Facebook, Twitter, Hi-5, alat berita sosial seperti Reddit, Digg Propeller, alat berbagi foto dan video seperti Youtube dan Flickr serta alat bookmark sosial seperti Simpy. Salah satu keuntungan dari iklan di media sosial adalah penargetan pasar yang tepat melalui penggunaan informasi demografis yang tersedia (Nosrati, Karimi, Mohammadi, \& Malekian, 2013).

Online advertising lebih menarik untuk konsumen karena para pengiklan fokus pada mereka untuk menyesuaikkan minat yang sebelumnya. Sebagai tambahan, periklanan online dapat hadir secara simultan di dalam beberapa variasi seperti video, sound clip, teks, dan kombinasi semuanya. Internet menjadi media periklanan yang sangat kuat karena dua alasan utama: pertama, hampir setiap rumah memiliki akses internet yang berkelanjutan. Kedua, internet memiliki khalayak harian yang jika dirata-ratakan jauh lebih besar daripada khalayak media tradisional sebelumnya. Kemungkinan mecapai target khalayak yang ditentukan merek, menginduksi efektivitas penjualan situs web, dan memungkinkan transfer informasi ke konsumen. Periklanan internet membantu produk dan jasa pasar melalui katalog-katalog yang interaktif dan berwarna serta menyediakan khalayak dengan informasi terkini. Saat ini terdapat berbagai jenis websites (Tavor, 2011)

Menurut Clark et al (1999) akuntabilitas di dalam periklanan adalah masalah penting dalam praktik serta riset pemasaran. Hal ini sudah banyak diteliti dalam hal periklanan offline. Namun, munculnya e-commerce serta meningkatnya tingkat pembelian online telat menciptakan peluang baru untuk melacak asal pembelian online. Sehingga, untuk pertama kalinya, efektivitas saluran periklanan online pada hasil dapat diukut dengan data yang nyata, bukan melalui eksperimen menurut Chatterjee et al (2003). Analisis efektivitas saluran periklanan dan perilaku konsumen telah muncul sebagai konsep kunci dalam disiplin 
pemasaran bagi para peneliti dan praktisi karena menjembatani perilaku konsumen dan strategi pemasaran (Brettel \& Spilker-Attig, 2010).

Menurut Paul Deshwal (2016) online advertising adalah jenis komunikasi massa yang didasarkan pada bentuk iklan tradisional tetapi mengembangkan strategi komunikasinya sendiri dalam berkorelasi dengan persyaratan teknis dan menengah yang baru. Secara luas, online advertising adalah tentang menayangkan iklan ke internet atau pengguna online melalui situs web, email, perangkat lunak yang didukung iklan, dan smartphone yang didukung internet. Contoh dari online advertising termasuk iklan kontekstual di mesin pencari halaman hasil, iklan banner, periklanan jaringan sosial, iklan pengantara, iklan baris online, jaringan iklan dan email pemasaran termasuk email spam dan lain-lain. Ada beberapa manfaat dari online advertising antara lain: harganya terjangkau dibandingkan dengan biaya periklanan tradisional, jangkauan geografis yang lebih luas, hanya membayar jika iklan dibuka, perhitungan hasil yang mudah, target khalayak yang lebih banyak, kecepatan pengiriman pesan yang lebih cepat dibandingkan periklanan tradisional (Deshwal, 2016).

Miller (2012) menyebutkan bahwa online advertising merupakan cara terbaik karena memiliki jenis yang berbeda dengan teknologi yang berbeda. Saat ini penggunaan jaringan internet terus meningkat. Selain itu, di dalam online advertising dapat ditampilkan berbagai macam jenis periklanan yang kreatif sehingga dapat membuat perbedaan yang besar. Menurut Calvert (2008) menemukan bahwa tren peningkatan dari iklan online membuat keluarga lebih rentan terhadap pemasaran. Menurut Lindstadt dan Budzinski (2012) banyak perusahaan yang sudah memperpanjang biaya pemasaran mereka untuk iklan online. Di sisi lain, periklanan online dibandingkan dengan jenis periklanan media lainnya bertujuan untuk memilih keunggulan bagi perusahaan pengiklanan (Hadadi \& Almsafir, 2014).

Stuart (2008) menemukan bahwa kategori-kategori media online termasuk portal-portal, konten, mesin pencari, media sosial, video, blog, email dan newsletters, e-commerce, RSS, dan ad network. Tipe-tipe dari online advertising adalah jaringan dan opsi berbeda. Kreativitas menjadi salah satu kunci penting di dalam kesuksesan online advertising. Menurut Bajpai, Pandey, dan Shriwas (2012) online advertising memiliki jenis-jenis yang berbeda. Salah satu cara yang paling popular di dalam online advertising adalah menggunakan jaringan sosial dimana konsumen dan shareholders memiliki bagian yang lebih dari sekedar hanya audiens (Hadadi \& Almsafir, 2014).

Beberapa jenis dari online advertising seperti iklan kontekstual di mesin pencari, iklan banner, pemasaran afiliasi, dan pemasaran email tradisional. Luo et al menyelidiki bagaimana penempatan pencarian iklan dapat memengaruhi daya ingat dan pengakuan merek oleh pengguna. Goldsmith dan Laffery menawarkan beberapa saran untuk iklan online, termasuk kepentingan medium, efektivitas iklan, dan sikap branding (Lin, Li, \& Wu, 2015).

Sebagai salah satu penyedia layanan telekomunikasi di Indonesia, Axis menjalankan beberapa kegiatan advertisingnya melalui digital. Tidak dapat dihindari lagi bahwa saat ini hampir sebagian besar perusahaan menggunakan internet dalam kegiatan pemasarannya. Untuk menjangkau pasar yang lebih luas lagi serta menyampaikan pesan sesuai dengan target perusahaan, berikut beberapa tipe online advertising yang dijalankan oleh Axis melalui digital:

\section{Search Engine Marketing (SEM)}

Search engine marketing merupakan sebuah bentuk marketing yang mencari untuk promosi website dengan meningkatkan visibilitasnya dalam mesin pencari atau search engine result pages (SERPs) melalui penggunaan baik itu paid placement, periklanan konteksual, dan paid 
inclusion. SEM juga dapat digunakan melalui teknik mesin pencarian optimisasi bebas (Priyanka, 2012).

Terdapat empat kategori dalam metode dan matrik yang digunakan untuk mengoptimalkan situs web melalui pemasaran mesin pencarian (Nosrati et al., 2013): kata kunci penelitian dan analisis melibatkan tiga langkah, kejenuhan dan popularitas situs web, alat back end, perangkat Whois.

Dalam menjalankan strategi pemasaran melalui online advertising, Axis menggunakan search engine marketing untuk mencari promosi website sehingga periklanan yang dijalankan oleh Axis di internet akan meningkat dalam visibilitasnya di mesin pencari.

\section{Search Engine Optimization (SEO)}

Search engine optimization merupakan suatu proses dari meningkatkan visibilitas website atau halaman web di mesin pencari melalui hasil pencarian "alami" atau tidak berbayar (Priyanka, 2012). Secara umum, yang lebih awal (atau peringkat lebih tinggi pada halaman hasil pencarian) dan semakin sering sebuah situs muncul dalam daftar hasil pencarian, maka akan semakin banyak pengunjung yang akan diterima dari pengguna mesin pencari. SEO dapat menargetkan berbagai jenis pencarian, termasuk pencarian gambar, pencarian video, pencarian berita, pencarian lokal, pencarian akademik, dan mesin pencari vertical khusus industri (Nosrati et al., 2013).

Sebagai strategi pemasaran internet, SEO mempertimbangkan bagaimana mesin pencari bekerja, istilah pencarian aktual, apa yang dicari orang, kata kunci yang diketikkan ke mesin pencari dan mesin pencari mana yang disukai oleh khalayak yang ditargetkan. Mengoptimalkan situs web dapat melibatkan pengeditan kontennya, HTML, dan pengkodean terkait dalam meningkatkan relevansinya dengan kata kunci tertentu serta untuk menghilangkan hambatan pada aktivitas pengindeksan mesin pencari. Mempromosikan situs untuk meningkatkan jumlah backlink, atau tautan masuk, adalah taktik dari SEO (Nosrati et al., 2013).

\section{Placement Banner}

Dengan adanya perkembangan perangkat digital dan software komputer, berbagai format dari periklanan telah dikenalkan di dalam iklan. Tren ini termasuk komersial TV dan juga online advertising. Di dalam online advertising, terdapat banner ads dengan pengaturan interaktif yang menarik bagi online advertising. Interaktivitas dapat menjadi alat yang efektif untuk online advertising karena online memungkinkan adanya komunikasi dua arah. Meskipun pesan itu sendiri diyakini sebagai elemen inti ketika pesan pemasaran dikomunikasikan, hal itu selalu menjadi perhatian besar bagi biro iklan untuk memutuskan elemen mana yang harus digunakan dan ditekankan. Hal ini bisa menjadi factor penting bagi keberhasilan kampanye iklan. Banner ads dapat dibagi menjadi ekspresi visual atau audio (Zia-ul, 2012).

Menurut Raman dan Leckenby (1998) banner advertisements atau iklan banner adalah tampilan persegi panjang pada halaman web yang menyajikan petunjuk bagi pengunjung untuk mengetahui lebih lanjut dengan mengklik banner tersebut. Mengklik pada banner membawa pengunjung dari halaman web saat ini ke halaman web pengiklan. Dengan cara ini, iklan banner digunakan sebagai wahana untuk mendatangkan calon pelanggan ke situs, menawarkan tautan otomatis ke pengiklan. Iklan banner yang dapat diklik dipercaya sebagai gerbang pertama untuk memasuki dunia pasar elektronik interaktif (Baltas, 2018).

Banner ads juga dapat didefinisikan sebagai gambar grafik di situs web dengan informasi yang menarik dan ringkas. Banner dapat menyertakan beberapa tajuk flash atau video untuk 
menarik konsumen (Horbal, Naychuk-Khrushch, \& Orlykova, 2017). Selain itu banner ads juga memiliki arti sebagai gambar yang ditempatkan di situs web hosting iklan dan hyperlink ke situs web sponsor yang membawa informasi produk dan promosi yang lebih rinci. Di dalam banner ads, terdapat rasio klik tayang dimana hal ini didefinisikan sebagai persentasi konsumen yang terpapar iklan dan yang benar-benar mengklik iklan untuk menuju ke situs web sponsor. Clickthrough rate merupakan metrik yang penting yang sering digunakan untuk menghitung tingkat efektivitas dari banner ads. Metrik ini juga digunakan secara luas untuk menentukan harga iklan banner (Ghosh \& Bhatnagar, 2013).

Untuk banner ads Axis, mereka menyebutkan nama periklanannya sebagai placement banner. Axis memasang iklan melalui in app games dimana mereka muncul di game-game yang memiliki inventory apps. Contohnya jika menonton video iklan Axis tersebut, pemain akan mendapatkan poin atau coin di dalam permainan yang sedang dimainkan. Cara ini dilakukan agar pemain game menjadi tertarik untuk meng klik iklan Axis karena mendapatkan keuntungan berupa poin atau coin untuk permainannya. Ketika pengguna game mulai membuka iklan Axis baik itu berupa foto maupun video, pengguna game akan memperhatikan iklan tersebut tanpa bisa menutup atau melewatkan iklan. Ketika pengguna game mulai melihat iklan, diharapkan pengguna game dapat sadar hingga akhirnya tergerak untuk membeli dan menggunakan kartu Axis.

Hal yang serupa dilakukan melalui media chatting line. Di dalam line, terdapat fitur poin yang dapat memiliki fungsi untuk membeli sticker ataupun theme. Iklan yang dipasang Axis melalui line menawarkan penukaran poin jika video iklan Axis diputar hingga selesai oleh pengguna line. Ketika iklan mulai di klik oleh pengguna platform, pengguna platform akan diarahkan ke dalam iklan Axis. Placement banner ini dilakukan oleh Axis untuk memperluas jangkauan target yang tidak hanya sekedar di media sosial, namun di aplikasi permainan.

\section{Social Media}

Kemajuan teknologi internet dan komunikasi telah memfasilitasi peningkatan di media sosial. Media sosial adalah platform berbasis internet yang menekankan interaksi manusia. Berdasarkan kategorisasi oleh Kaplan dan Haenlein, proyek kolaborasi, blog, komunitas konten, situs jejaring sosial, dunia game virtual, dan dunia sosial virtual adalah semua jenis media sosial. Lebih jauh lagi, Heinonen mencatat bahwa aktivitas di dalam media sosial dapat dikategorikan dengan motivasi. Fitur yang ditawarkan oleh media sosial secara umum dibagi menjadi tiga yaitu proses informasi, aktivitas hiburan, dan koneksi sosial. Kategori dari fungsi tersebut menyiratkan bahwa media sosial menyediakan platform terbuka untuk komunikasi timbal balik, difusi informasi, dan interaksi sosial (Lin et al., 2015).

Dengan meningkatnya media baru ini, perusahaan mengeksplorasi peluang bisnis dan iklan online sebagai salah satu usaha komersial paling popular. Periklanan online memiliki beberapa bentuk dan strategi implementasi yang berbeda. Fiorillo mengatakan bahwa mengenai saluran distribusi iklan, tercatat bahwa periklanan sosial dapat mendistribusikan iklan yang sesuai melalui jejaring sosial pengguna. Banyak peneliti telah mengusulkan model iklan online yang tersedia dari situs web media sosial. Menggunakan iklan online di media sosial adalah hal yang penting dan dapat diterapkan. Bagherjeiran dan Parekh mencatat bahwa hubungan sosial dan interaksi sosial antara pengguna adalah factor penting dalam mewujudkan kegiatan periklanan sosial (Lin et al., 2015)

Periklanan media sosial menjadi online advertising selanjutnya yang umumnya digunakan. Hal ini dapat dilihat dari jaringan sosial yang terkenal seperti Twitter, Facebook, Instagram Pinterest. Jenis periklanan ini menggabungkan beberapa opsi target khusus untuk membuat iklan lebih efektif seperti (Horbal et al., 2017) : 
Penargetan geografis yang menentukan lokasi web pengguna situs dan memberikan iklan sesuai dengan wilayah, kota, tempat, organisasi, atau bahkan bioskop tertentu dengan bantuan yang menempatkan iklan terkait dengan tempat tertentu

Iklan kontekstual yang menganggap kemunculan pada halaman yang diakses oleh pengguna setelah pengguna mencari halaman internet tertentu dengan kata kunci

Iklan perilaku, tugas penting dimana mengumpulkan data tentang halaman web yang dikunjungi konsumen, sesi waktu, klik per tayangyang dibuatnya, kata-kata kunci yang diketik di browser. Jadi ketika memasuki situs web lebih lanjut, pengunjung dapat menghadapi iklan tertentu sesuai dengan hasil mesin pencari terbaru mereka

Melihat target khalayak yang ingin dicapai oleh Axis, memasang periklanan di media sosial merupakan salah satu hal yang tepat karena target khalayak Axis merupakan anak muda hingga dewasa dimana pada usia tersebut mereka sedang aktif menggunakan media sosial dalam kehidupan sehari hari. Axis menempatkan online advertising di dalam berbagai platform di media sosial. Untuk platform berbagi video, Axis menggunakan Youtube dalam memasang iklan. Iklan yang di unggah di dalam youtube merupakan iklan yang dipasang di video pengguna lainnya dengan jumlah subscriber yang sudah tinggi dan iklan yang dipasang di dalam akun Axis sendiri. Iklan di dalam Youtube milik Axis biasanya berdurasi 15 detik hingga 45 detik.

Axis juga menggunakan Twitter, Facebook, dan Instagram dalam melakukan online advertising. Pemasangan iklan di masing-masing platform digunakan untuk menjangkau khalayak yang aktif menggunakan social networking sites. Saat ini. Twitter, Instagram, dan facebook menyediakan alokasi untuk iklan oleh perusahaan-perusahaan yang ingin mempromosikan produk dan jasanya. Di dalam twitter, iklan akan muncul dalam bentuk tweet yang ditandai dengan promoted di timeline kita walaupun kita tidak mengikuti akun twitter Axis. Iklan dalam bentuk tweet ini akan muncul di tengah-tengah akun yang kita ikuti. Di dalam Instagram, iklan akan muncul di tengah-tengah unggahan akun yang kita ikuti. Iklan di Instagram muncul dalam bentuk unggahan foto atau video Axis di feed maupun instastory.

Selain di social networking sites, Axis juga menggunakan media chatting untuk menjangkau khalayaknya melalui online advertising salah satunya yaitu melalui line. Line menyediakan ruang untuk para pengiklan memasang iklan mereka.

Media sosial diharapkan dapat membantu penggunanya membangun brand awareness terhadap Axis dimana jika iklan Axis muncul secara berkala di platform yang sering digunakan penggunanya, maka mereka akan mulai menyadari mengenai bentuk produk yang ditawarkan oleh Axis beserta promosi-promosi didalamnya dimana hasil akhirnya diharapkan dapat membangun keputusan untuk membeli dan menggunakan Axis sebagai operator seluler yang digunakan sehari-hari.

Berdasarkan penuturan dari Ibu Sharon, Digital Campaign Youth Marketing Communication Axis dan Marketing Communication Axis, alasan mengapa Axis menggunaka media sosial yaitu sebagai berikut:

"Karena kita mau reach target segmennya. Karena sekarang Axis tuh 1323 yang dimana target segmen Axis tuh dalam sehari 5 jam mereka gunain di handphone dan 90\% dari 5 jam itu mereka menggunakan sosial media" 


\section{Online Advertising Sebagai Pemasaran Axis}

Branding dan penjualan secara langsung merupakan alasan mengapa perusahaan membayar untuk online advertising. Branding mencoba untuk meningkatkan nilai yang dirasakan dari suatu produk atau jasa dari perusahaan terhadap pelanggan sedangkan iklan penjualan langsung mencoba untuk membujuk konsumen untuk segera bertindak, dengan mengklik iklan, melalukan panggilan telepon, atau melakukan kegiatan lain (Brajnik \& Gabrielli, 2010).

Online advertising menjadi tipe strategi marketing yang melibatkan penggunaan internet untuk promosi produk dengan mengirimkan pesan pemasaran yang lebih besar kepada konsumen. Hal ini meliputi pengiriman iklan kepada pengguna internet melalui situs web, email, perangkat lunak yang didukung iklan, pesan teks, dan telepon seluler yang didukung internet di dalamnya. Di dalam pemasaran online, konsumen, bukan pemasar, yang memberikan izin dan mengendalikan interaksi. Konsumen internet memiliki akses sepanjang waktu ke berbagai sumber informasi, menjadikan mereka pembeli informasi yang lebih baik dan lebih cerdas (Kalia \& Mishra, 2016).

Saat ini telekomunikasi modern dan teknologi informasi sudah semakin aktif diimplementasikan di kehidupan sosial sehingga hal ini juga mengubah bagaimana produk dan jasa diproduksi dan dipasarkan. Itulah sebabnya industri informasi memainkan peran besar dalam pengembangan pasar global dan internasional serta menentukan pertumbuhan prospektifnya. Kemajuan dalam teknologi komunikasi telah memengaruhi penciptaan teknik pemasaran yang inovatif dan pemasaran internet adalah salah satu yang paling dinamis. Pengguna internet telah menjadi segmen penting konsumen yang dapat memengaruhi perkembangan bisnis yang stabil. Periklanan online cenderung menjadi salah satu metode pemasaran yang paling penting terkait dengan para pengguna internet. Internet menjadi salah satu sarana utama komunikasi antara orang-orang dalam bisnis maupun kehidupan pribadi. Intensitas fenomena ini terus tumbuh bersamaan dengan internet yang cenderung memainkan peran penting sebagai saluran baru pemasaran dan periklanan internasional (Horbal et al., 2017).

Periklanan selalu menjadi faktor penting dalam memasarkan produk. Selama masyarakat terus berkembang, bentuk dan metode periklanan ikut berubah. Dalam hal globalisasi perusahaan mempertahankan daya saingnya di pasar yang mengarah pada penerapan alat pemasaran modern, khususnya periklanan di internet. Maka dari itu tujuan menentukan fitur, tujuan iklan online, dampaknya terhadap penjualan, dan cara mempromosikan bisnis melalui internet menjadi semakin relevan. Iklan internet dapat didefinisikan sebagai segala bentuk komunikasi antara konsumen dan penerbit, yang menggabungkan iklan melalui email, halaman mesin pencari, banner, dan lain-lain. Tujuan utama online advertising adalah meningkatkan penjualan yang dapat dicapai dengan menarik lebih banyak konsumen melalui akses intenet. Alasan lain penggunaan online advertising yaitu untuk meningkatkan kesadaran merek dengan memberikan informasi tentang fitur eksklusif yang dimiliki oleh merek yang sedang diiklankan (Horbal et al., 2017)

Online advertising memiliki beberapa tujuan seperti (Horbal et al., 2017):

Membangun kesadaran merek (brand awareness) yang memainkan peran besar di dalam marketing. Menempatkan beberapa informasi eksklusif yang dimiliki merek yang dapat membuat pelanggan membeli produk. Meningkatkan penjualan dengan menghadirkan produk di situs web suatu produk. Saat ini tersedia cara yang sangat mudah untuk membeli barang hanya dengan mengkliknya. Menciptakan permintaan terhadap produk atau jasa kemudian memuaskannya. 
Efektivitas periklanan adalah salah satu masalah penelitian terpenting di dalam pemasaran. Pengiklan terus berupaya menerapkan program alokasi sumber daya media yang memaksimalkan laba atas investasi media. Keberhasilan implementasi program semacam itu membutuhkan pemahaman yang jelas tentang peran uang media dalam membujuk segmen sasaran untuk membeli produk yang diiklankan. Sebagian besar upaya ini berkisar pada keputusan penempatan media yang terutama bergantung pada jangkauannya. Sementara sebagian besar penelitian yang ada tentang efektivitas periklanan berfokus pada jangkauan dan frekuensi, beberapa peneliti juga mengidentifikasi peran penting dari pesan iklan. Penelitian telah menunjukkan bahwa iklan mengubah persepsi konsumen tentang produk yang diiklankan (Ghosh \& Bhatnagar, 2013).

Bagaimana pun juga, dilakukannya online advertising karena dilihat adanya keuntungan dengan menggunakan media internet di dalam mengiklankan suatu produk. Beberapa keuntungan dari online advertising yaitu (Deshwal, 2016) :

a. Lebih murah : keuntungan yang utama dari online advertising yaitu harganya yang lebih terjangkau dibandingkan dengan periklanan tradisional. Melalui internet, periklanan dapat dilakukan dengan biaya yang lebih murah serta jangkauan khalayak yang lebih luas

b. Jangkauan geografis yang lebih luas : online advertising memberikan jangkauan kampanye yang lebih global sehingga membantu menjangkau lebih banyak khalayak. Hal ini dapat membantu mencapai hasil yang lebih unggul melalui strategi online advertising

c. Tidak ada pembayaran ketat : dalam periklanan tradisional, anda harus membayar jumlah uang penuh ke biro iklan, terlepas dari bagaimana hasilnya. Namun di dalam online advertising, anda hanya membayar jika sudah ada aktivitas klik, arahan, atau tayangan yang berkualitas

d. Pengukuran hasil yang mudah : fakta bahwa pengukuran hasil dari iklan membuat online advertising menjadi lebih menarik daripada metode periklanan tradisional. Di dalam online advertising, terdapat banyak alat analitik yang efektif dalam mengukur hasil online advertising

e. Lebih banyak target khalayak : dibandingkan dengan iklan tradisional, online advertising membantu dalam menjangkau khalayak yang ditargetkan, sehingga dapat mengarahkan pada kesuksesan kampanye iklan

f. Kecepatan : online advertising lebih cepat dibandingkan aktivitas iklan offline apapun sehingga dapat menjangkay target khalayak dalam waktu singkat

g. Informatif : dalam online advertising, pengiklan dapat menyampaikan rincian lebih lanjut tentang iklan kepada khalayak dengan biaya yang relative lebih rendah

h. ROI yang lebih baik : karena online advertising utamanya focus pada pembayaran berbasis kinerja, maka ROI akan lebih baik dibandingkan dengan iklan offline

i. Keterlibatan khalayak yang lebih mudah : sebagian besar platform periklanan online memudahkan penonton untuk ikut terlibat di dalam iklan atau produk yang ditayangkan. Khalayak dapat memberikan umpan balik kepada pengiklan

j. Branding yang lebih baik : segala bentuk iklan membantu dalam meningkatkan branding namun online advertising memiliki fungsi meningkatkan branding yang cukup tinggi

Online advertising merupakan salah satu cara yang dilakukan oleh Axis dalam strategi pemasaran produk mereka. Axis sebagai salah satu produk telekomunikasi di Indonesia memahami bagaimana ketatnya persaingan antar provider saat ini. Kompetisi mengenai harga 
dan layanan yang ditawarkan setiap provider menjadi semakin ketat dari waktu ke waktu. Untuk tetap bisa bersaing dalam kompetisi ini, Axis memanfaatkan internet sebagai salah satu media yang saat ini digunakan banyak orang di dalam memperkenalkan dan mempromosikan produknya.

Bertambahnya jumlah pengguna internet dari waktu ke waktu membuat persiangan dalam periklanan kemudian memanfaatkan online advertising untuk mencapai target khalayak yang lebih luas di dalam waktu yang singkat. Online advertising juga dianggap sebagai salah satu media yang lebih interaktif di dalam penyampaian pesan dalam bentuk iklannya. Iklan di dalam media digital saat ini juga tidak hanya terbatas dalam bentuk foto atau gambar, namun sudah dapat bentuk video berdurasi pendek. Berbagai macam jenis online advertising dilakukan oleh Axis agar dapat menjangkau khalayak dari berbagai jenis platform yang ada di internet.

Dalam menjalankan online advertising yang ingin dibentuk oleh Axis, terdapat beberapa tahapan yang dilakukan berdasarkan penuturan Ibu Sharon sebagai berikut:

"Yang perlu disiapkan dalam menjalankan online adveritising adalah kita tentukan dulu objectivenya apa. Lalu kita tentukan target marketnya siapa, lalu kita tentukan budgetnya berapa. Untuk evaluasinya, digital platform bisa dibilang paling efektif. Kenapa? Karena marketing panel mulai dari awareness, consideration, sampai paling ujungnya adalah purchase, itu kita bisa target dan kita bisa hitung efektivitasnya".

Di dalam persiapan memasang online advertising, Axis melakukan penetapan objective untuk masing-masing iklan yang akan mereka pasang. Objective yang ingin dicapai ini menjadi langkah awal sehingga tujuan dan target khalayak Axis sesuai. Setelah objective sudah ditentukan, Axis menentukan target market mulai dari sisi usia, demografi, geografi, dan juga harga. Setelah target khalayak sudah ditentukan, selanjutnya menentukan perencanaan biaya atau budgeting di dalam online advertising untuk setiap jenis iklan yang mereka keluarkan. Rencana biaya merupakan langkah untuk persetujuan apakah iklan akan diterbitkan dengan dana yang tersedia atau tidak.

Sharon, Digital Campaign Youth Marketing Communication Axis dan Marketing Communication Axis, menjelaskan bagaimana melihat efektivitas dari platform yang dijalankan melalui online advertising:

"Kalo awareness biasanya kita lihat dari reach, kalo consideration kita liat dari click through rate yang masuk ke platform-platoform Axis, kalo purchase kita matching data dari platform kita sama data yang dimiliki dari tim product which is real purchase"

Dalam melihat efektivitas yang sudah dijalankan oleh Axis melalui platform yang tersedia di internet, Axis melakukan penilaian melalui clickthrough rate. Clickthrough rate dilakukan untuk melihat perhitungan banner ads yang sudah dikeluarkan oleh Axis di internet.

\section{KESIMPULAN}

Sebagai salah satu perusahaan operator seluler di Indonesia, Axis melakukan kegiatan online advertising melihat saat ini perkembangan teknologi digital semakin pesat sehingga kegiatan bisnis menjadi lebih efektif jika dilakukan melalui digital. Online advertising yang dijalankan oleh Axis merupakan salah satu langkah untuk membangun kesdaran masyarakat terhadap produk Axis. Tujuan akhir dari online advertising ini yaitu mempengaruhi masyarakat untuk membeli dan menggunakan kartu Axis serta layanan yang ada di dalamnya. 
Di dalam menjalankan strategi online advertising, Axis melakukan beberapa jenis online advertising mulai dari SEO, SEM, Media Sosial, dan Placement Banner. Hal ini dilakukan untuk mencapai target market Axis yang sudah ditetapkan dari awal.

\section{DAFTAR PUSTAKA}

Ahmed, R. R., Streimikiene, D., Berchtold, G., Vveinhardt, J., Channar, Z. A., \& Soomro, R. H. (2019). Sustainability Effectiveness of Online Digital Media Advertising as A Strategic Tool for Building Brand Sustainability : Evidence from FMCGs and Services Sectors of Pakistan.

Anusha, G. (2016). Effectiveness of Online Advertising, 4.

Armstrong, G., Stewart, A., Denize, S., \& Kotler, P. (2015). Principles of Marketing. Melbourne: Pearson Australia.

Baltas, G. (2018). Determinants of Internet Advertising Effectiveness: An Empirical Study. International Journal of Market Research, 45(4), 1-9. https://doi.org/10.1177/147078530304500403

Brajnik, G., \& Gabrielli, S. (2010). A review of online advertising effects on the user experience. International Journal of Human-Computer Interaction, 26(10), 971-997. https://doi.org/10.1080/10447318.2010.502100

Brettel, M., \& Spilker-Attig, A. (2010). Online advertising effectiveness: A cross-cultural comparison. Journal of Research in Interactive Marketing, 4(3), 176-196. https://doi.org/10.1108/17505931011070569

Deshwal, P. (2016). Online advertising and its impact on consumer behavior. International Journal of Applied Research, 2(2), 200-204. Retrieved from www.allresearchjournal.com

Ghosh, H., \& Bhatnagar, A. (2013). On Measuring and Increasing the Effectiveness of Banner Advertising. MIS Review, 19(1), 25-44. https://doi.org/10.6131/MISR.2013.1901.02

Hadadi, K., \& Almsafir, M. K. (2014). The Impact of Online Advertising on Proton Sales among Expatriates in Malaysia. Procedia - Social and Behavioral Sciences, 129, 274-281. https://doi.org/10.1016/j.sbspro.2014.03.677

Horbal, N., Naychuk-Khrushch, M., \& Orlykova, B. (2017). Internet advertising: the specifics, tendencies of development and impact on sales. An International Quarterly Journal, 6(1), 37--46. Retrieved from file:///C:/Users/User/Downloads/Horbal NaychukKhrushch_Orlykova.pdf

Hutabarat, D. (2018). Inilah Rincian Jumlah Pelanggan Prabayar Masing-Masing Operator. Retrieved May 21, 2019, from https://kominfo.go.id/content/detail/

Kalia, G., \& Mishra, D. A. (2016). Effects of online Advertising on Consumers. IOSR Journal of Humanities and Social Science, 21(09), 35-41. https://doi.org/10.9790/08372109013541

Kireyev, P., Pauwels, K., \& Gupta, S. (2016). Do display ads influence search? Attribution and dynamics in online advertising. International Journal of Research in Marketing, 33(3), 475-490. https://doi.org/10.1016/j.ijresmar.2015.09.007 
Kotler, P., Burton, S., Deans, K., Linen, B., \& Armstrong, G. (2013). Marketing. Australia: Pearson Australia Group Pty Ltd.

Lim, Y., Yap, C., \& Lau, T. (2011). The Effectiveness of Online Advertising in Purchase Decision : Liking, Recall and Click. Australian Journal of Basic and Applied Sciences, 5(9), 15171524.

Lin, L. F., Li, Y. M., \& Wu, W. H. (2015). A social endorsing mechanism for target advertisement diffusion. Information and Management, 52(8), 982-997. https://doi.org/10.1016/j.im.2015.07.004

Nosrati, M., Karimi, R., Mohammadi, M., \& Malekian, K. (2013). Internet Marketing or Modern Advertising ! How ? Why ? International Journal of Economy, 2(3), 56-63.

Oh, S., Oh, J. S., \& Shah, C. (2008). The Use of Information Sources by Internet Users in Answering Questions, 1-13.

Priyanka, S. (2012). a Study on Impact of Online Advertising on Consumer Behavior (With Special Reference To E-Mails). International Journal of Engineeering and Management Sciences, 3(4), 461-465. Retrieved from www.onlineadvertising.com

Schwarzl, S. (2015). Online marketing strategies:, 8(2), 187-196. https://doi.org/10.14254/2071-8330.2015/8-

Tavor, T. (2011). Online Advertising Development and Their Economic Effectiveness. Australian Journal of Business and Management Research, 1(6), 121-133.

Whitney, F. (1960). The Elements of Research (Asian Edition). Osaka: Overseas Book Co.

Zia-ul, H. (2012). Online Banner Advertising : A study of Consumer Responses to Various Factors, 5, 1-10. 